\title{
НЕСТАНДАРТНАЯ ЛЕКСИКА В ПОЛЬСКОМ КИНОПЕРЕВОДЕ ФИЛЬМА „ШИРлИ-МЫРли”
}

\author{
Ивона Mытык
}

\section{NON-STANDARD VOCABULARY IN THE POLISH FILM TRANSLATION OF THE FILM „WHAT A MESS!”}

\begin{abstract}
Iwona Mytyk
Резюме: В статье рассматривается проблема перевода фильмов с русского языка на польский. Прежде всего, представлены трудности перевода нестандартной лексики (низких коллоквиализмов, арго, обсценной лексики). Исследовательским материалом был выбран фильм российского кинопроизводства „Ширли-мырли" и его польский перевод в субтитрах. Автор оценивает методы перевода и конечный эффект перевода стилистически сниженной лексики.
\end{abstract}

Ключевые слова: кино, аудиовизуальный перевод, нестандартная лексика

Abstract: The article presents the problem of translating films from Russian into Polish. First of all, the problem of translating non-standard vocabulary (low colloquialisms, argo, obscene vocabulary) is shown. The research material is the Russian film "What a Mess!" and its Polish translation in subtitles. The author evaluates the translation methods and the final effect of the translation of stylistically reduced vocabulary.

Key words: cinema, audiovisual translation, non-standard vocabulary

DOI: $10.14712 / 9788076032088.13$

Широко известно, что перевод фильмов - непростая задача. Однако если все сделано хорошо, это может значительно способствовать успеху фильма в форме признания со стороны кинокритиков и других специалистов этой индустрии по всему миру. Перевод ненормативной лексики - одна из трудностей, с которой сталкивается переводчик кинокартин в своей работе. Важно, чтобы переводчик учитывал социальные нормы и культуру общества, для которого он переводит. В данной статье мы попытаемся проанализировать методы перевода ненормативной лексики на польский язык при переводе субтитров фильма российского кинопроизводства. Цель нашего исследования - показать современные способы перевода ненормативных языковых единиц и трудности, с которыми столкнулся переводчик. Материалом для исследования послужили польские субтитры к фильму „Ширли-мырли” Владимира Меньшова. Перевод субтитров сделан польской кинокомпанией „Фильмострадой” („Filmostrada”).

Развитие языка и общества влечет за собой постоянное появление новых единиц как стандартной, так и нестандартной лексики. Знание этого слоя лексики необходимо для лучшего понимания носителей языка, современной литературы, средств массовой информации и современного кино. В любом языке одна и та же мысль может выражаться по-разному - всё зависит от ситуации. Существуют нейтральные слова, которые употребляются независимо от 
сферы коммуникации и являются ядром языка. Вторая группа - это слова стилистически окрашенные, используемые в определенных ситуациях и определенными группами общества. Такие слова мы называем нестандартной лексикой. Она подразделяется на низкие коллоквиализмы (просторечная лексика), общий сленг, специальный сленг (жаргоны и арго), а также обсценную лексику (Беляева 1985, 15). Такой лексикон используется, чтобы украсить речь, показать эмоции, снять стресс и даже оскорбить людей. Как видим, функции этих типов слов разнообразны.

В польском языке ненормативная лексика считалась языковым табу и нередко опускалась в переводах. Языковые табу трансформировались, и результатом стало увеличение частоты использования ненормативной лексики не только в повседневном общении, но и в средствах массовой информации, литературе и кино. Эти единицы являются проблемой перевода, поскольку они стали неотъемлемым элементом языковой стилизации и, таким образом, входят в состав важного языкового слоя текста. В переводе фильмов наблюдается тенденция употребления смягчённых форм выражений. Есть, конечно, разные взгляды на перевод нестандартной лексики. Переводчик Юрий Сербин считает, что в переводе не может быть крайностей. Мы не можем говорить о полном отсутствии ненормативной лексики или о переводе каждого "уродливого» слова. Самое главное, чтобы переводчик учел замечания заказчика, поскольку именно он определяет, в какой степени в переводе могут использоваться вульгарные слова. Польский переводчик фильмов Петр Маевский утверждает, что переводчики пытаются делать универсальные переводы. Это объясняется тем, что один и тот же вариант перевода может транслироваться по телевидению в любое время, не нарушая телевизионных правил.

Как уже было сказано, в качестве материала для исследования будет использована российская комедия „Ширли-мырли” и ее перевод в виде субтитров на польский язык. Выбор комедии объясняется богатой базой ненормативной лексики, содержащейся в фильме. Приблизим сюжет фильма. На сайте kinopoisk.ru можно прочитать, что это невероятная история о братьях-близнецах, никогда прежде не слыхавших друг о друге. Один из них, в младенчестве подброшенный в табор, стал цыганским бароном; другой же рос в детском доме - и теперь он еврей-музыкант с мировым именем; третьего воспитывала родная тетя, и домашнее воспитание принесло свои плоды: он стал авторитетнейшим в СНГ вором и аферистом. Именно он, благодаря своим талантам, обводит вокруг пальца главу мафии и похищает фантастический алмаз «Спаситель России». Стоимость найденного в Сибири драгоценного камня такова, что вся страна смогла бы в течение трех лет отдыхать на Канарских островах.

Мы разделили ненормативную лексику, которая появляется в фильме, на три категории:

1. Низкие коллоквиализмы;

2. Арго;

3. Обсценная лексика.

Напомним вкратце смысл отдельных категорий. Итак, низкие коллоквиализмы определяются как слой общеизвестной и общеупотребительной бытовой лексики и фразеологии с шутливо-иронической и фамильярно-насмешливой экспрессией и основной коммуникативноэмотивной функцией (Коровушкин 2005, 19). Концепция сленга смешивается с такими понятиями, как арго. Это видно в случае второй группы. К арго относятся слова, отграниченные употреблением какой-либо социальной группой, особенно расширенные в криминальных кругах. Ученые до сих пор не пришли к единому мнению, относить ли арго к специальному сленгу или считать его отдельной группой нестандартной лексики. Третья категория - обсценная 
лексика. Она описана как сегмент бранной лексики различных языков, включающий вульгарные, грубые и грубейшие (похабные, непристойные) бранные выражения, часто выражающие спонтанную речевую реакцию на неожиданную (обычно неприятную) ситуацию (Жельвис 2001, 176).

Фильм является художественным произведением, а значит, субъективным. Однако перевод фильма - это вопрос сохранения объективности по отношению к переведенному художественному произведению. Теория Скопоса предполагает, что переводчик должен быть верным содержанию, а не тексту. В результате нестандартная лексика, которая появляется в фильме, является частью текста и может подвергаться процессам интерпретации. Наиболее распространенные методы перевода ненормативной лексики - это:

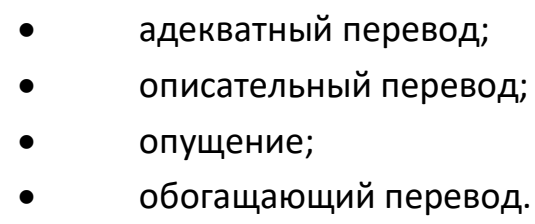

По мнению Комиссарова, именно „адекватный перевод обеспечивает прагматические задачи переводческого акта на максимально возможном для достижения этой цели уровне эквивалентности, не допуская нарушения норм или узуса - употребления слов и их форм, закрепившихся в речи переводящего языка, соблюдая жанрово-стилистические требования к текстам данного типа и соответствуя общественно-признанной конвенциональной норме перевода" (Комиссаров 1990, 128). Указывая последние методы, необходимо помнить о том, что описательный перевод заключается в передаче значения иностранного слова при помощи более или менее распространенного объяснения. Критикуемый метод - перевод, ориентированный на опущение в тексте нестандартной лексики. Это является следствием феномена непереводимости, который представляет собой сложную проблему для всех переводчиков. Последний метод - обогащающий перевод, наименее используемый. В случае с кино мы можем сказать, что он вообще не используется.

Проанализируем некоторые примеры перевода нестандартной лексики. Для начала рассмотрим категорию низких коллоквиализмов.

1. Ой! Как сейчас помню. [...] А вы кричите, сиську просите. /Pamiętam, jak dzisiaj. [...] A wy krzyczycie, chcecie jeść./

2. Пока она с пузом ходила, он ей всё на рояле играл Бетховена там. /Gdy była w ciq̨ży, on grał jej na fortepianie Beethovena./

Вышеуказанные реплики произнесены тетей, которая рассказывает, как случилось, что три брата были разлучены. В оригинале использовалась стилистически сниженная лексика, как просить сиську, ходить с пузом. Следует добавить, что тетя часто использует такой тип лексики в своих высказываниях, поэтому можно смело утверждать, что это характерная черта ее речевого стиля. В польской версии мы наблюдаем, что нестандартная лексика заменяется нейтральной лексикой литературного стандарта. Таким образом, переводчик лишает зрителя информации о стиле актерской речи, что важно в случае комедии.

Вторая категория показывает лексику, связанную с криминальной сферой. 
1. Фёдор Павлович? А он по какому предмету? - Да он по сейфам был специалист. Медвежатник. /Fiodor Pawłowicz? A czego on uczył? Był specjalistq od sejfów. Kasiarz./

2. Они всё врут, на секрете держат. Только один раз прокололись. /Oni wszystko utrzymujq jako ściśle tajne. Tylko raz wyszło na jaw./

3. Под придурка решил косить. /Wymyślit, że będzie udawać wariata./

4. Васька - молоток! Коси под цыгана до упора. /Waśka! Udawaj cygana do oporu./

5. А менты будут сидеть, рот разинув. /A gliny będq siedzieć i patrzé́./

6. И думать ничего. Врываемся в ментовку, музыканта в мешок. /Co tu dużo dyskutować. Włamiemy się do komisariatu. Muzykanta w worek./

В первом и пятом примере мы наблюдаем использование слов из воровской сферы медвежатник, значит „преступник, специализирующийся на взломах сейфов”, а также мент, в этом смысле - „полицейский”. Здесь переводчик решил предоставить адекватный перевод, используя эквивалентную лексическую замену. В данном случае - это польские слова kasiarz и gliniarz. В шестом примере при переводе слова ментовка (отделение милиции) переводчик решил выбрать лексику без криминальной окраски. Он использовал слово нейтрального стандарта. В четвертой реплике актер употребил слово молоток, которое согласно жаргонному воровскому словарю значит молодец.

В польской версии переводчик использует метод опущения. В переводе слово из криминальной сферы было убрано. В третьем примере используется интересное словосочетание косить под придурка, которое значит „притворяться безумным”. Во втором примере мы также наблюдаем интересный глагол криминальной окраски проколоться, обозначающий „потерпеть неудачу”. В этих случаях переводчик совершил замену на нейтральное словарное соответствие.

Сейчас перейдем к последней категории, , т.е. к обсценной лексике.

1. Глаза у тебя здоровые. Только ты, козёл, на голову больной, с детства. /Oczy to Ty masz zdrowe. Tylko Ty, capie, od dziecka chorujesz na głowę./

2. Васька Кроликов, сука!/Waśka! Sukinsyn!/

3. Убью суку! /Zabije jq./

4. Ты ещё здесь, блядь заморская? /Ty jeszcze jesteś tutaj, zdziro zagraniczna?/

5. Испугались, демократы хреновы! /Co, przestraszyliście się? Pieprzeni demokraci./

6. Ты смотри, какой туман-то в Москве. Ни хрена не видно. /Zobacz, jaka mgła w Moskwie. Gówno widać./

Первые четыре примера представляют обсценную лексику, которая подпадает под группу оскорблений, то есть под группу, которую мы определяем как умышленное унижение чести и достоинства человека, выраженное в некультурной форме. В оригинале мы наблюдаем популярные русские оскорбления, то есть козёл и сука, а также блядь. Во втором и третьем примерах появляется одно и то же слово. В то время как во втором примере переводчик нашел польский аналог („sukinsyn”), в третьем примере оскорбление было удалено из перевода. Таким 
образом, реплика была лишена эмоциональных оттенков. В четвертом примере переводчик также использовал польский эквивалент („zdzira”), но в первом примере наблюдаем более интересную реплику. Актриса использует оскорбление козёл по отношению к своему родственнику, который критикует ее за то, что она не убирает квартиру. Польская версия вызывает сомнения. В представленном контексте поляки редко используют слово сар. В этой ситуации они бы предпочли использовать kretyn, głupek. Возможно, переводчик хотел остаться в лексиконе животных. В последних примерах мы видим продуктивную обсценную лексику на русском языке, а именно - хрен. Она используется в форме существительного (Ни хрена не видно) и прилагательного (демократы хреновы), а также наречия (чувствую себя хреново). Переводчик решил использовать польские эквиваленты, которые полностью отражают речь и эмоции актера.

Примеры, взятые из комедии „Ширли-мырли”, подтверждают, что перевод нестандартной лексики является сложным вопросом в контексте практики перевода. Следует отметить, что в большинстве случаев переводчик использовал такие методы, как замена на нейтральную лексику, а также выбор эквивалентов. В связи с тем, что кинодиалог в фильме строго ограничен временными рамками, переводчик также прибегает к опущению части информации. К сожалению, этот выбор связан и с потерей эмоций в актерских репликах.

\section{Использованная литература/ References}

БЕЛЯЕВА, Т. М., Хомяков В.А. (1985): Нестандартная лексика английского языка. Ленинград: Изд-во ЛГУ, 1985. 138. ISBN 5-8114-0045-4.

ЖЕЛЬВИС, В.И.(2001): Поле брани. Сквернословие как социальная проблема. Москва: Ладомир, 2001. 350. ISBN 5-86218-090-7.

КОМИССАРОВ, В.Н. (1990): Теория перевода (лингвистические аспекты). Москва: Высшая школа, 1990. 253. ISBN 5-06-001057-0.

КОРОВУШКИН, В. П. (2005): Основы контрастивной социолектологии. Череповец: гОУ ВпО ЧГУ, 2005. 284. ISBN 5-85341-199-3.

\section{Профиль автора:}

Ивона Мытык, аспиратка

Научные интересы: кино, аудиовизуальный перевод, теория перевода

e-mail: imytyk@gmail.com

Место работы: Педагогический университет, Краков, ул. Подхоронжых 2, 30-084, Польша

\section{Author`s profile:}

Iwona Mytyk, PhD student

Scientific interests: Cinema, Audiovisual Translation, Translation Studies

e-mail:imytyk@gmail.com

Place of work: Pedagogical University of Cracow, Cracow, 2 Podchorazych Street, 30-084, Poland 